\title{
Removal Characteristics of Organic Pollutants from Eutrophic Raw Water by Biological Pretreatment Reactors
}

\author{
Guangcan Zhu, ${ }^{1,2}$ Zhonglian Yang, ${ }^{1}$ and Xiwu $\mathrm{Lu}^{1,2}$ \\ ${ }^{1}$ School of Energy and Environment, Key Laboratory of Environmental Medicine Engineering, Ministry of Education, \\ Southeast University, Nanjing, Jiangsu 210096, China \\ ${ }^{2}$ Wuxi Engineering Research Center of Lake Taihu Water Environment, Southeast University, Wuxi, Jiangsu 214135, China \\ Correspondence should be addressed to Guangcan Zhu; gc-zhu@seu.edu.cn
}

Received 21 April 2016; Accepted 29 June 2016

Academic Editor: Jun Wu

Copyright (C) 2016 Guangcan Zhu et al. This is an open access article distributed under the Creative Commons Attribution License, which permits unrestricted use, distribution, and reproduction in any medium, provided the original work is properly cited.

\begin{abstract}
Two biological contact oxidation reactors, cascade biofilm reactor (CSBR) and one-step biofilm reactor (OSBR), were used in this paper for pretreatment of eutrophic water from Lake Taihu in China. The CSBR was more effective and stable for eutrophic water treatment than OSBR, in terms of extracellular microcystin-LR, chlorophyll-a, DOC, and biodegradable dissolved organic carbon (BDOC) removal. Removal efficiencies of extracellular microcystin-LR and chlorophyll-a were $75.8 \%$ and $59.7 \%$ in CSBR and $60.5 \%$ and $53.0 \%$ after $2 \mathrm{~h}$ in OSBR. CSBR had much higher removal efficiency $(34.3 \%)$ than OSBR (22.7\%) for DOC, and CSBR could remove $67 \%$ BDOC, accounting for $34 \%$ of total DOC in source water. $11.5 \%$ of DOC was removed through means other than biological degradation, such as biofilm adsorption and bioflocculation. In CSBR at 5.5 13 $\mathrm{C}, 57.5 \%$ of atrazine was removed at $2 \mathrm{~h}$ hydraulic retention time, with background concentration of $136.5 \mathrm{ng} / \mathrm{L}$. Meanwhile, removal efficiencies of three phthalic acid esters (PAEs) (dimethyl phthalate, di-(2-ethylhexyl) phthalate, and di-n-butyl phthalate) were $78.7 \%, 52.4 \%$, and $85.3 \%$, respectively. Only $35.2 \%$ of polycyclic aromatic hydrocarbons (PAHs) could be removed by CSBR with initial concentration of $21.5 \mu \mathrm{g} / \mathrm{L}$. The results indicated that CSBR is effective in low-molecular-weight organic pollution pretreatment and provides benefits in terms of effluent quality.
\end{abstract}

\section{Introduction}

A large amount of nitrogen, phosphorous, and other components can be entered into natural lake water due to the discharge of pollutants into a water body. The excess existence of these elements will lead to lake eutrophication, algal blooms, and massive accumulation of harmful organic micropollutants. Lake Taihu, the third-largest freshwater lake in China, has received increasing amounts of waste from industrial, agricultural, and municipal development, as a result of rapid economic development and related urbanization along the lake. As Wang et al. indicated, two hundred and seventy-three kinds of organic chemicals in water from Taihu Lake were examined, 200 more than those detected in 1985. Among them 21 kinds of chemicals belong to priority pollutants and 17 kinds are the endocrine disruptors. The number of organic pollutants recorded in their tests is 3.6 times that determined in 1985, while concentrations of some pollutants were more than 2 times higher than in 1985 [1].

Organic pollutants in eutrophic water mainly include algal toxins, pesticides, persistent organic pollutants (POPs) such as polychlorinated biphenyls (PCBs), dioxins, and furans; endocrine disruptors (EDs) such as polycyclic aromatic hydrocarbons (PAHs) and phthalate esters (PAEs); and humic acids, which are precursors of disinfection byproducts. Many organic pollutants have toxic effects on the human liver, kidneys, immune system, endocrine system, and reproductive system. Moreover, these organic pollutants might have the potential to cause abnormalities, cancer, and mutation. In the Meiliang Bay area of Lake Taihu, the average levels of microcystins (MCs) could reach as high as 10 $18 \mu \mathrm{g} / \mathrm{L}$ in summer [2]. Significant mutagenic activities have been detected in Lake Taihu, and the estrogen-like potential of the lake has also been estimated, with recorded estradiol 


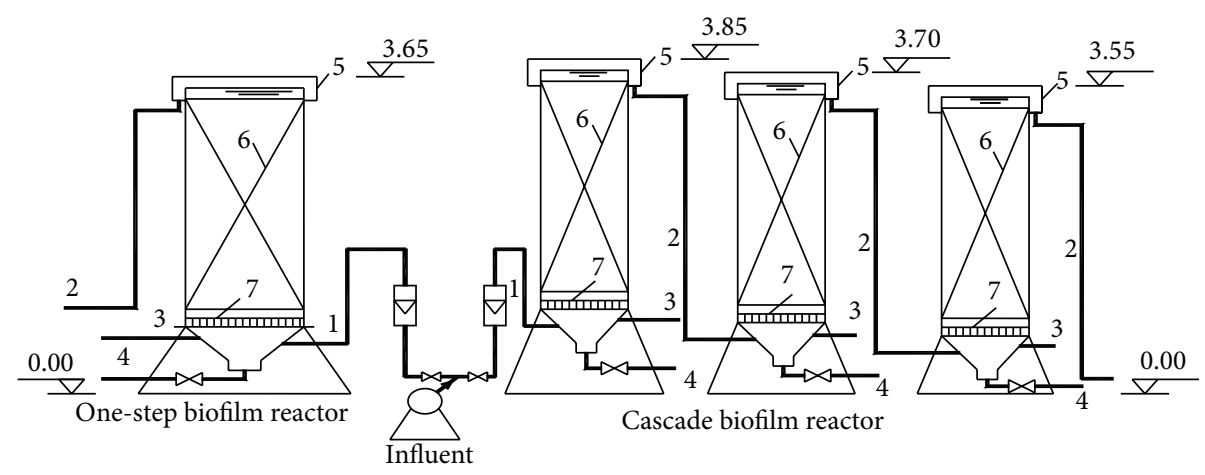

FIGURE 1: The schematic diagram of two biological pretreatment reactors. CSBR: cascade biofilm reactor; OSBR: one-step biofilm reactor. 1. Inlet pipe, 2. outlet pipe, 3. air inlet pipe, 4. mud pipe, 5. effluent flume, 6. filler, and 7. water and air arrangement plate. Reactor size: the OSBR is square: length $\times$ width $=600 \times 600 \mathrm{~mm}$; the cells of CSBR are round; the diameter of each cell is $380 \mathrm{~mm}$.

equivalents in the range of $2.2 \sim 12.1 \mathrm{ng} / \mathrm{L}$, levels that are sufficient to affect the reproduction of aquatic life [3]. The concentration of PAHs and di-(2-ethylhexyl) phthalate (DEHP) in Lake Taihu was 9.06 15.57 $\mu \mathrm{g} / \mathrm{L}$ and 9.0 12.0 $\mu \mathrm{g} / \mathrm{L}$, respectively, in the years 2002-2003 [4]. Accordingly, it is quite necessary to increase dissolved organic matter (DOC) removal performance regarding drinking water treatment.

The conventional drinking water treatment process, comprised of coagulation, sedimentation, sand filtration, and disinfection stages, is inefficient in removing DOC, with removal efficiencies amounting to only $20 \% \sim 30 \%[4,5]$. It has been reported that DOC can be removed through biological processes [6]. Their research indicated that the highest removal efficiency during biological treatment (attached growth biomass in a flow through bioreactor) was $59 \pm 15 \%$ and $35 \pm 9.3 \%$ for cyclophosphamide and ifosfamide, respectively. Falås et al. found that several compounds such as bezafibrate, atenolol, and acyclovir were significantly removed in the activated sludge process fed with municipal wastewater [7]. Phan et al. investigated the performance of a side-stream ceramic nanofiltration membrane bioreactor (NF-MBR) system with respect to basic water quality parameters as well as trace organic contaminant (TrOC) removal efficiency. The result of significantly higher performance by this NF-MBR regarding the removal of a large number of TrOCs was observed [8].

The objective of this study was to investigate the biological pretreatment of organic pollutants in the eutrophic Lake Taihu raw water, for the enhanced treatment, safety, and quality of drinking water. Two biological contact oxidation reactors, cascade biofilm reactor (CSBR) and one-step biofilm reactor (OSBR), were adopted in this research.

\section{Experimental}

2.1. Site Description and Reactor Design. The pilot test was conducted in Wuxi Water Works, in Nanquan Town, China, near the north side of Lake Taihu.

The CSBR was composed of 3 cells (Figure 1), with a height difference of $0.15 \mathrm{~m}$; water in the columns could flow through gravity based on this design. The OSBR had the same reaction volume as the CSBR $\left(1 \mathrm{~m}^{3}\right)$ with the same filler height of $3 \mathrm{~m}$.

2.2. Reactor Operating Conditions and Sample Collection. The raw water from Lake Taihu was pumped to the individual reactors. The hydraulic retention time of both reactors was $2 \mathrm{~h}$. The gas-water ratio was $1.5: 1$ for each reactor. Samples were collected when the reactors were both in steady state operation.

The basic water quality parameters of raw water from Lake Taihu were summarized as follows: water temperature was from $5.5^{\circ} \mathrm{C}$ to $13^{\circ} \mathrm{C}$, turbidity was from $6 \mathrm{NTU}$ to $20 \mathrm{NTU}$, $\mathrm{NH}_{4}{ }^{+}-\mathrm{N}$ concentration was from $0.1 \mathrm{mg} / \mathrm{L}$ to $0.3 \mathrm{mg} / \mathrm{L}$, and permanganate index $\left(\mathrm{COD}_{\mathrm{Mn}}\right)$ was within $5 \mathrm{mg} / \mathrm{L} \sim 9 \mathrm{mg} / \mathrm{L}$. All of the experiments were replicated 2 3 times and the average values were used for the calculation of removal efficiencies.

2.3. Analytical Reagents. A guide sample of microcystin-LR was purchased from Sigma (USA). Guide samples of atrazine, three phthalic acid esters (dimethyl phthalate (DMP), di(2-ethylhexyl) phthalate (DEHP), and di-n-butyl phthalate (DBP)), and 16 US EPA priority PAHs (naphthalene (Naph), acenaphthylene (Aceph), acenaphthene (Ace), fluorine (Fl), phenanthrene (Phe), anthracene (An), fluoranthene (Flu), pyrene (Pyr), benzo[a]anthracene (BaA), chrysene (Chr), benzo[b]fluoranthene $(\mathrm{BbF})$, benzo[k]fluoranthene $(\mathrm{BkF})$, benzo[a]pyrene (BaP), indeno[1,2,3-cd]pyrene (Inp), dibenzo[a,h]anthracene (DBA), and benzo[ghi]perylene $(\mathrm{BgP}))$ in a mixture solution of $2000 \mu \mathrm{g} / \mathrm{mL}$ were purchased from Supelco (USA). All solid phase extraction C18 columns were purchased from Waters Sep-Pak (USA). All organic solvents for microorganics were obtained from commercial sources with at least reagent grade.

2.4. Analytical Methods. Chlorophyll-a, an important indicator for phytoplankton, was analyzed by acetone extraction spectrophotometry; the final chlorophyll-a analysis was concerned with absorbance at $645 \mathrm{~nm}, 663 \mathrm{~nm}$, and $750 \mathrm{~nm}$. Total microcystin-LR (TMC-LR) and extracellular microcystin-LR 
(EMC-LR) were analyzed by high performance liquid chromatography (HPLC, Agilent 1100, USA) with a photodiode array detector and Agilent ZORBAX 80A extend column $(5 \mu \mathrm{m}, 4.6 \times 150 \mathrm{~mm})$.

DOC was detected using the TOC automeasuring device TOC- $\mathrm{V}_{\mathrm{CSH}}$ (Shimadzu, Japan). The collected samples were pretreated with filtration $(0.45 \mu \mathrm{m})$, before being run through the column for dissolved total carbon (DTC) and dissolved inorganic carbon (DIC) detection. The difference between DTC and DIC was assigned as DOC. BDOC was determined as explained below. Firstly, the water sample DOC was assigned as $\mathrm{DOC}_{0}$. Then, a $250 \mathrm{~mL}$ sample was inoculated with a $5 \mathrm{~mL}$ bacteria suspension, which was made from the biofilm peeled off from the filler. Finally, the samples were incubated at $25 \pm 0.5^{\circ} \mathrm{C}$ for 28 days for $\mathrm{DOC}_{28}$ determination. In the final analysis, $\mathrm{BDOC}=\mathrm{DOC}_{0}-\mathrm{DOC}_{28}$.

Atrazine, three phthalic acid esters (PAEs) species, and polycyclic aromatic hydrocarbons (PAHs) were all determined by gas chromatography (Shimadzu, GC-2001, Japan). First, a $1 \mathrm{~L}$ water sample was enriched by $\mathrm{C} 18$ solid phase extraction column. In the second stage, the C18 solid phase extraction column was then eluted using methanol, ethyl acetate, and hexane solution containing 5\% of isopropanol for eluent. Third, the eluent was concentrated and the final volume was diluted to $1.0 \mathrm{~mL}$. Finally, the concentrations of atrazine, PAEs, and PAHs were detected using gas chromatography. The electron capture detector (ECD) was used for atrazine and PAEs while the flame ionization detector (FID) was used for PAHs.

\section{Results and Discussion}

3.1. Removal of Chlorophyll-a and Microcystin-LR. The enrichment of algal biomass in eutrophic water was accompanied by chlorophyll-a accumulation. As shown in Figure 2, the Chl- $a$ of raw water was $18.75 \mu \mathrm{g} / \mathrm{L}$. The observation of the water samples under microscope revealed blue-green algae as the dominant algal species with a small size. CSBR and OSBR achieved Chl-a removal efficiencies of $59.7 \%$ and $53 \%$, respectively.

The removal of algae by biological pretreatment may occur through the following mechanisms: adsorption by biofilm; microbial oxidation and decomposition; mechanical retention and biological flocculation by filler; prey by microanimals; biological flocculation; and algal sedimentation by biofilm off the filler. Because of their small size, it is difficult for blue-green algae to be removed by mechanical retention. Therefore algae removal should mainly rely on biofilm adsorption, biological flocculation and sedimentation, and the role of microanimals.

Microcystins, mainly produced by freshwater blue-green algae, are the most common algal toxins. They have the highest occurrence frequency in cyanobacteria blooms and have already resulted in very serious impacts on people $[9,10]$. Among microcystins, microcystin-LR (MC-LR) has been shown to be one of the most toxic and harmful algal toxins [11]. As shown in Figure 3, the concentration of total microcystin-LR (TMC-LR) in Taihu raw water was

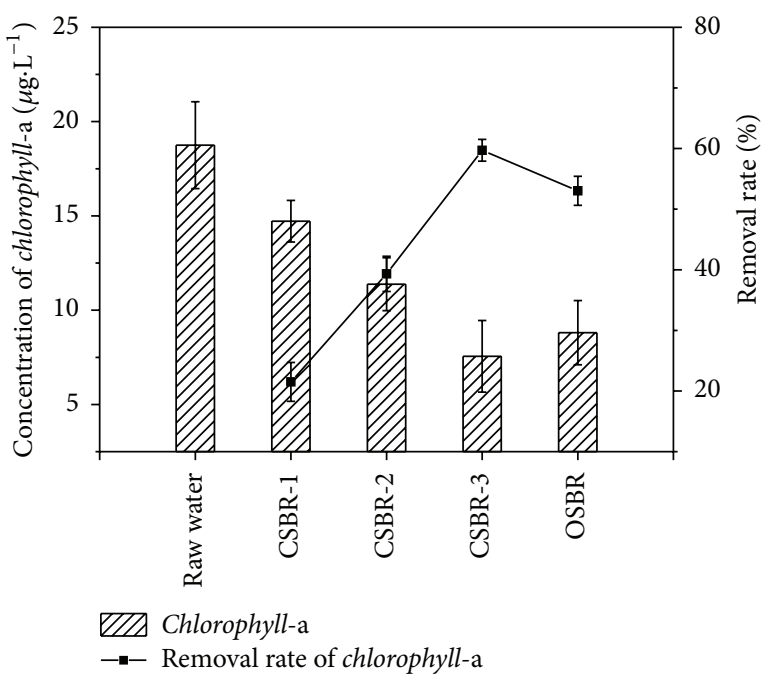

FIGURE 2: Removal of chlorophyll-a by two reactors.



FIGURE 3: Removal of microcystin-LR by two reactors.

$2.65 \mu \mathrm{g} / \mathrm{L}$, while the extracellular microcystin-LR (EMC-LR) was $2.15 \mu \mathrm{g} / \mathrm{L}$. The data indicated that most of the microcystin was EMC. The CSBR had removal efficiencies of $65.3 \%$ and $75.8 \%$ for TMC-LR and EMC-LR, respectively, $12.5 \%$ and $15.3 \%$ higher than the corresponding results in OSBR. The removal efficiencies of TMC-LR throughout the three steps of CSBR were $28.7 \%, 24.1 \%$, and $12.5 \%$, respectively. In addition, CSBR could achieve removal efficiencies of $23.7 \%, 33 \%$, and $19.1 \%$ for EMC-LR through the three steps. This indicated that MC was removed mainly by step one and step two. The MC removal efficiency of OSBR was only equal to the removal rates achieved by the first two steps of CSBR, showing that CSBR had a much higher efficiency for microcystin immobilization and degradation.

3.2. Removal of DOC and BDOC. Figure 4 listed the removal efficiencies of DOC and BDOC in the two reactors. These results indicated that CSBR showed good removal properties 




FIgURE 4: Removal of dissolved organic matter (DOC) and biodegradable dissolved organic matter (BDOC) by two reactors.

(about 34.3\%) in removing dissolved organic carbon (DOC) in Taihu raw water, while OSBR only removed about $22.7 \%$ of DOC. Most of the DOC was removed in the first step and the concentration of DOC had slightly increased in the second step. This may have been caused by the release of some particulate organic matter into water, which contributed to an increase in DOC.

Biodegradable DOC (BDOC) refers to soluble organic compounds in water which can be decomposed by bacteria to $\mathrm{CO}_{2}$ and water or to other materials used for cell metabolism [12]. Thus, removing BDOC by biological pretreatment before water entering the conventional treatment process can help secure drinking water quality. The concentration of BDOC in Lake Taihu raw water was $1.58 \mathrm{mg} / \mathrm{L}, 30.4 \%$ of total DOC. The removal efficiencies of BDOC in CSBR and OSBR were examined to be $67.1 \%$ and $54.4 \%$, respectively. CSBR had a much higher BDOC degradation efficiency than that of OSBR (Figure 4). In CSBR, the treatment of BDOC and DOC was mainly attributed to biodegradation. The ratio of BDOC to DOC decreased in the following columns, indicating that the biodegradability gradually lowered along the flow path. By comparison, CSBR achieved removal efficiencies of about $34.3 \%$ for DOC and $67.1 \%$ for BDOC. However, BDOC accounted for $30.4 \%$ of the total DOC in raw water, indicating that $22.8 \%$ of the total DOC was removed as BDOC. Thus, about $11.5 \%$ of DOC was removed by mechanisms other than biological degradation, such as biofilm adsorption and bioflocculation.

3.3. Removal of Atrazine in CSBR. Atrazine is one of the most widely used herbicides in the world and has had a wide range of applications in China since the 1980s. Atrazine is classified as a suspicious substance because of the presence of environmental hormones (endocrine disrupters) and is considered by the United Nations to be one of 27 persistent toxic substances, due to its large consumption, long residual

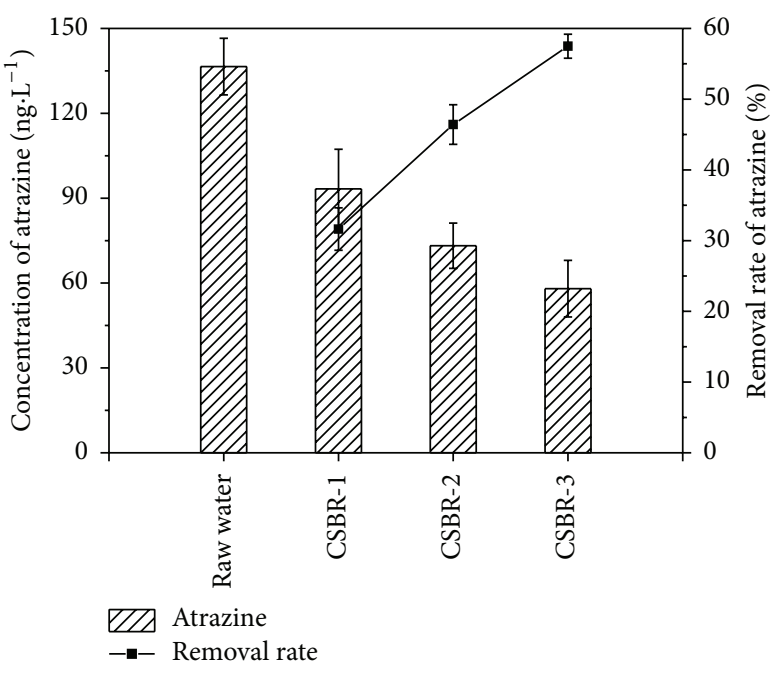

FIgURE 5: Removal of atrazine by cascade biofilm reactor.

period (a half-life of 244 days), and possible carcinogenic effects in human and mammals $[13,14]$.

Typical conventional processes, such as coagulation and sedimentation, lime softening, and chlorination, are not effective in the removal of atrazine and other herbicides [15]. Even enhanced coagulation cannot remove atrazine in raw water [16]. This is because processes of coagulation, sedimentation, and filtration mainly remove organics with molecular weight greater than 10,000 daltons. Due to the fact that atrazine has a much smaller molecular weight (about 216 daltons), conventional processes have almost no purification effect on it.

The background concentration of atrazine in Lake Taihu was $136.5 \mathrm{ng} / \mathrm{L}$. The CSBR could reach a satisfactory removal efficiency for atrazine (about 57.5\%, Figure 5). Even at low temperature conditions $\left(5.5 \sim 13^{\circ} \mathrm{C}\right), 31.6 \%$ of removal efficiency was achieved in the first step, with removal efficiencies of $14.8 \%$ and $11.1 \%$ in the second and third steps, respectively. Microbes probably contributed to the degradation of atrazine. A variety of microbes have been isolated from bacteria, fungi, actinomycetes, and algae, including Pseudomonas spp., Agrobacterium sp., Penicillium, Trichoderma, white rot fungi, Ankistrodesmus, and so forth. Some of these microbes, notably bacteria, have very good atrazine removal efficiencies [17].

3.4. Removal of PAHs in CSBR. Phthalic acid esters (PAEs), a group of important organic chemicals, have a wide range of applications in many industries and have become one of the most common pollutants in the world. Studies on the reproductive toxicity of PAEs show that these substances have endocrine effects on organisms and can cause proliferation of cancer cells. The toxicity may even have intergenerational effects through the placenta and through breastfeeding [18]. Track detection of PAEs in several water works in Zhejiang Province showed that DBP was detected in all measured drinking water, with the highest concentration of about $76 \mu \mathrm{g} / \mathrm{L}$; DEHP had a detected rate of $50 \%$, with the highest 


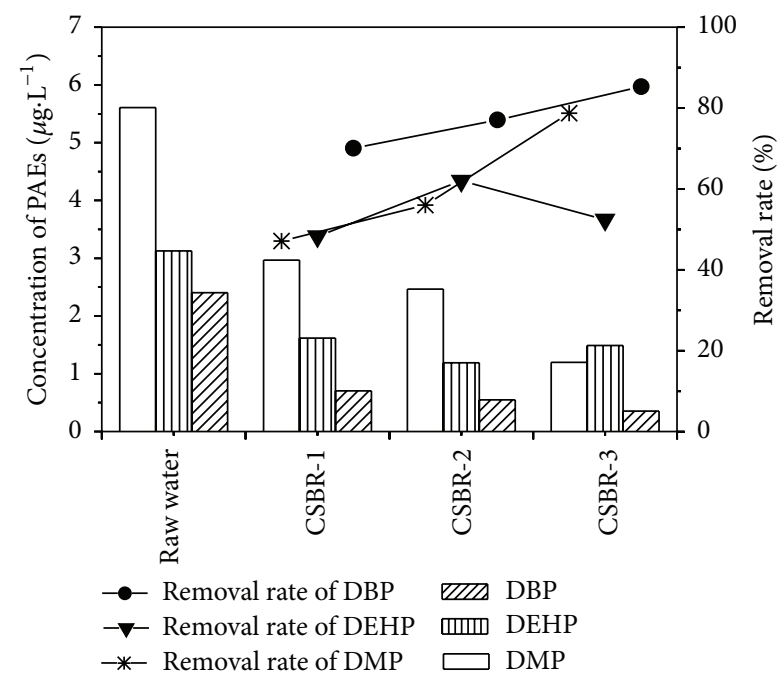

FIgURE 6: Removal of three kinds of PAEs by cascade biofilm reactor.

concentration at approximately $17 \mu \mathrm{g} / \mathrm{L}$ [19]. This means that urban water plants with conventional treatment processes are ineffective in removing PAEs.

Three kinds of PAEs (DMP, DEHP, and DBP) were selected for the investigation of removal characteristics via biocontact oxidation pretreatment. The background concentrations of DMP, DEHP, and DBP were $5.61 \mu \mathrm{g} / \mathrm{L}, 3.13 \mu \mathrm{g} / \mathrm{L}$, and $2.40 \mu \mathrm{g} / \mathrm{L}$, respectively (Figure 6). The removal efficiency in CSBR for DBP was significantly higher (85.3\%) than that for DMP (78.6\%) and DEHP (52.3\%); this might be due to structural complexity differences between the substances. Metabolic breakdown of PAEs by microorganisms is considered to be one of the major pollutant removal pathways, due to their low removal rates by other processes of hydrolyzation and photodecomposition [20]. Many bacterial strains isolated from diverse habitats, such as Rhodococcus sp. L4 and Pseudomonas fluorescens FS1, have been found to have the ability to degrade PAEs $[21,22]$.

3.5. Removal of PAHs in CSBR. PAHs are widely distributed in the atmosphere, water, mud, and soil and are the result of incomplete combustion of coal, oil, gas, cigarettes, barbecues, and so forth or leakage of crude oil or refined oil to a water body [23]. More than 400 kinds of PAHs have been found to have carcinogenic effects. Many of these substances are considered to have significant side effects on humans and animals, such as immunotoxicity, genotoxicity, and reproductive toxicity.

The background concentration of total PAHs in Lake Taihu was $21.51 \mu \mathrm{g} / \mathrm{L}$, considerably higher than the guide criterion of PAHs $(<2.0 \mu \mathrm{g} / \mathrm{L})$, which indicated that Lake Taihu had been heavily polluted by PAHs. Among 16 US EPA priority PAHs (Table 1), the concentrations of indeno(1,2,3cd) pyrene, benzo(k)fluoranthene, benzo(b)fluoranthene, benzo(a)anthracene, and acenaphthylene were notably higher than $2.0 \mu \mathrm{g} / \mathrm{L}$. The concentrations of PAHs containing 4 to 6 rings were generally higher than those of others, which was in agreement with the examination results of PAHs
TABLE 1: The removal rate of PAHs by cascade biofilm reactor $(\mathrm{CSBR}) / \mu \mathrm{g} \cdot \mathrm{L}^{-1}$.

\begin{tabular}{|c|c|c|c|c|c|}
\hline Name & Rings & $\begin{array}{l}\text { Raw } \\
\text { water }\end{array}$ & CSBR-1 & CSBR-2 & CSBR-3 \\
\hline Naphthalene & 2 & 1.084 & 1.396 & 1.597 & 1.395 \\
\hline Acenaphthene & 3 & 1.746 & 0.907 & 1.415 & 0.870 \\
\hline Acenaphthylene & 3 & 2.164 & 5.171 & 3.694 & 3.331 \\
\hline Fluorene & 3 & 0.105 & 0.069 & 0.072 & 0.098 \\
\hline Phenanthrene & 3 & 0.108 & 0.064 & 0.065 & 0.063 \\
\hline Anthracene & 3 & 0.533 & 0.264 & 0.261 & 0.275 \\
\hline Fluoranthene & 4 & 1.130 & 0.303 & 0.283 & 0.360 \\
\hline Pyrene & 4 & 0.720 & 0.179 & 0.944 & 0.142 \\
\hline Benzo(a)anthracene & 4 & 2.907 & 1.644 & 1.919 & 2.648 \\
\hline Chrysene & 4 & ND & ND & ND & ND \\
\hline Benzo(b)fluoranthene & 5 & 2.495 & 1.722 & 0.93 & 1.461 \\
\hline Benzo(k)fluoranthene & 5 & 2.960 & 0.090 & 0.167 & 0.168 \\
\hline Benzo(a)pyrene & 5 & 0.990 & 2.472 & 1.816 & 0.923 \\
\hline Indeno(1,2,3-cd)pyrene & 6 & 3.082 & 1.028 & 1.486 & 1.793 \\
\hline Dibenzo(a,h)anthracene & 5 & 1.314 & 0.146 & 0.033 & 0.148 \\
\hline Benzo(g,h,i)perylene & 6 & 0.169 & 0.480 & 0.104 & 0.191 \\
\hline $\begin{array}{l}\text { Total amount of PAHs } \\
\left(\mu \mathrm{g} \cdot \mathrm{L}^{-1}\right)\end{array}$ & & 21.507 & 15.935 & 14.786 & 13.866 \\
\hline Removal rate (\%) & & & 25.6 & 30.9 & 35.2 \\
\hline
\end{tabular}

Note: PAHs: polycyclic aromatic hydrocarbons. ND means the substance was not detected.

concentrations in the Meiliang Bay region of Lake Taihu in 2003 [24].

Biological pretreatment showed a relatively low removal efficiency $(35.2 \%)$ for PAHs compared to other organic micropollutants (Table 1). Some substances (naphthalene, acenaphthylene, benzo(a)pyrene, and benzo(g,h,i)perylene) even showed higher concentration in the effluent of CSBR. The increase in concentrations of several PAHs might be attributed to by-products generation from the biodegradation of other substances. The continuous accumulation of PAHs on the biofilm might also cause the release of PAHs in the effluent, due to the relatively lower biodegradability rates and short hydraulic retention time (HRT) $(2 \mathrm{~h})$ in the reactor. It had been reported that $90 \%$ of PAHs could been biodegraded only when a contact time of about 30 60 days or even much longer was applied [25, 26]. Therefore, for the treatment of drinking water, PAHs should be removed by advanced treatment processes, such as ozone-biological activated carbon process.

\section{Conclusions}

(1) The CSBR was more effective and stable than the OSBR for the treatment of eutrophic water, in terms of the removal efficiency of extracellular microcystinLR, chlorophyll-a, DOC, and BDOC.

(2) In CSBR, the removal of BDOC and DOC was mainly attributed to biodegradation. $11.5 \%$ of DOC was 
removed in ways other than biological degradation, such as through biofilm adsorption and bioflocculation.

(3) The CSBR could effectively promote atrazine and PAEs removal. $57.5 \%$ of atrazine was removed at $2 \mathrm{~h}$ HRT with a background concentration of $136.5 \mathrm{ng} / \mathrm{L}$. The removal efficiencies of three PAEs were $78.7 \%$, $52.4 \%$, and $85.3 \%$, respectively. Regarding PAHs, only $35.2 \%$ could be removed by the CSBR with an initial PAHs concentration of $21.5 \mu \mathrm{g} / \mathrm{L}$ in raw water.

(4) The CSBR was more effective in pretreatment of lowmolecular-weight organic pollution, and this reactor benefitted the improvement of effluent quality regarding drinking water treatment process.

\section{Competing Interests}

The authors declare that they have no competing interests.

\section{Acknowledgments}

This work was financially supported by the National Major Program of Science and Technology for Water Pollution Control and Restoration of China (2014ZX07405002 and 2012ZX07403-001).

\section{References}

[1] H. Wang, C. X. Wang, W. Z. Wu, Z. Mo, and Z. J. Wang, "Persistent organic pollutants in water and surface sediments of Taihu Lake, China and risk assessment," Chemosphere, vol. 50, no. 4, pp. 557-562, 2003.

[2] P. P. Shen, Q. Shi, Z. C. Hua et al., "Analysis of microcystins in cyanobacteria blooms and surface water samples from Meiliang Bay, Taihu Lake, China," Environment International, vol. 29, no. 5, pp. 641-647, 2003.

[3] J. H. Shen, B. Gutendorf, H. H. Vahl, L. Shen, and J. Westendorf, "Toxicological profile of pollutants in surface water from an area in Taihu Lake, Yangtze Delta," Toxicology, vol. 166, no. 1-2, pp. 71-78, 2001.

[4] R. P. Ji, Study on effect and mechanism of artificial media on the improvement of Taihu Lake water quality [Ph.D. dissertation], School of Energy and Environment, Southeast University, Nanjing, China, 2005.

[5] F. Ribas, J. Frías, J. M. Huguet, and F. Lucena, "Efficiency of various water treatment processes in the removal of biodegradable and refractory organic matter," Water Research, vol. 31, no. 3, pp. 639-649, 1997.

[6] M. Česen, T. Kosjek, M. Laimou-Geraniou et al., "Occurrence of cyclophosphamide and ifosfamide in aqueous environment and their removal by biological and abiotic wastewater treatment processes," Science of the Total Environment, vol. 527-528, pp. 465-473, 2015.

[7] P. Falås, A. Wick, S. Castronovo, J. Habermacher, T. A. Ternes, and A. Joss, "Tracing the limits of organic micropollutant removal in biological wastewater treatment," Water Research, vol. 95, pp. 240-249, 2016.
[8] H. V. Phan, J. A. McDonald, F. I. Hai et al., "Biological performance and trace organic contaminant removal by a sidestream ceramic nanofiltration membrane bioreactor," International Biodeterioration \& Biodegradation, 2016.

[9] J. Mankiewicz-Boczek, I. Karwaciak, M. Ratajewski et al., "Application of cellular biosensors for detection of atypical toxic bioactivity in microcystin-containing cyanobacterial extracts," Aquatic Toxicology, vol. 168, pp. 1-10, 2015.

[10] G. A. Codd, "Cyanobacterial toxins: occurrence, properties and biological significance," Water Science and Technology, vol. 32, no. 4, pp. 149-156, 1995.

[11] C. Keil, A. Forchert, J. Fastner et al., "Toxicity and microcystin content of extracts from a Planktothrix bloom and two laboratory strains," Water Research, vol. 36, no. 8, pp. 2133-2139, 2002.

[12] N. Gupta, S. C. Pant, R. Vijayaraghavan, and P. V. L. Rao, "Comparative toxicity evaluation of cyanobacterial cyclic peptide toxin microcystin variants (LR, RR, YR) in mice," Toxicology, vol. 188, no. 2-3, pp. 285-296, 2003.

[13] M. Zhang, M. J. Semmens, D. Schuler, and R. M. Hozalski, "Biostability and microbiological quality in a chloraminated distribution system," Journal of the American Water Works Association, vol. 94, no. 9, pp. 112-122, 2002.

[14] T. E. Stoker, S. C. Laws, D. L. Guidici, and R. L. Cooper, "The effect of atrazine on puberty in male Wistar rats: an evaluation in the protocol for the assessment of pubertal development and thyroid function," Toxicological Sciences, vol. 58, no. 1, pp. 50-59, 2000.

[15] Y. Ji, C. Dong, D. Kong, J. Lu, and Q. Zhou, "Heat-activated persulfate oxidation of atrazine: implications for remediation of groundwater contaminated by herbicides," Chemical Engineering Journal, vol. 263, pp. 45-54, 2015.

[16] B. B. Chen, N. Y. Gao, and C. Liu, "Study on removal of atrazine in source water by powdered aetivated carbon at burst pollution accident," Water \& Wastewater, vol. 33, pp. 9-13, 2007 (Chinese).

[17] V. V. Khromonygina, A. I. Saltykova, L. G. Vasil'chenko, Y. P. Kozlov, and M. L. Rabinovich, "Degradation of the herbicide atrazine by the soil mycelial fungus INBI 2-26 (-), a producer of cellobiose dehydrogenase," Applied Biochemistry and Microbiology, vol. 40, no. 3, pp. 285-290, 2004.

[18] M. Matsumoto, M. Hirata-Koizumi, and M. Ema, "Potential adverse effects of phthalic acid esters on human health: a review of recent studies on reproduction," Regulatory Toxicology and Pharmacology, vol. 50, no. 1, pp. 37-49, 2008.

[19] G. G. Han, P. G. Wu, and H. H. Wang, "Pollution of municipal water supply system by phthalates and evaluation on purification effects of current water treatment process $(\mathrm{Ch})$, , Journal of Environmental Health, vol. 18, pp. 155-156, 2001 (Chinese).

[20] C. A. Staples, D. R. Peterson, T. F. Parkerton, and W. J. Adams, "The environmental fate of phthalate esters: a literature review," Chemosphere, vol. 35, no. 4, pp. 667-749, 1997.

[21] Y. Lu, F. Tang, Y. Wang et al., "Biodegradation of dimethyl phthalate, diethyl phthalate and di-n-butyl phthalate by Rhodococcus sp. L4 isolated from activated sludge," Journal of Hazardous Materials, vol. 168, no. 2-3, pp. 938-943, 2009.

[22] F. Zeng, K. Y. Cui, X. D. Li, J. M. Fu, and G. Y. Sheng, "Biodegradation kinetics of phthalate esters by Pseudomonas fluoresences FS1," Process Biochemistry, vol. 39, no. 9, pp. 11251129, 2004.

[23] M. Nadal, M. Schuhmacher, and J. L. Domingo, "Levels of PAHs in soil and vegetation samples from Tarragona County, Spain," Environmental Pollution, vol. 132, no. 1, pp. 1-11, 2004. 
[24] M. Qiao, C. X. Wang, S. B. Huang, D. H. Wang, and Z. J. Wang, "Composition, sources, and potential toxicological significance of PAHs in the surface sediments of the Meiliang Bay, Taihu Lake, China," Environment International, vol. 32, no. 1, pp. 2833, 2006.

[25] Y. Xia, H. Min, D.-P. Zhou, and R.-Y. Han, "Characteristics and phylogenetic analysis of two phenanthrene-degrading bacteria," China Environmental Science, vol. 23, no. 2, pp. 162-166, 2003 (Chinese).

[26] M. Robert, S. Peter, and S. J. Heinrich, "Ex-situ process for treating PAH-contaminated soil with phanerochaete chrysosporium," Environmental Science and Technology, vol. 31, no. 9, pp. 2626-2633, 1997. 



Carbohydrate Chemistry



The Scientific World Journal
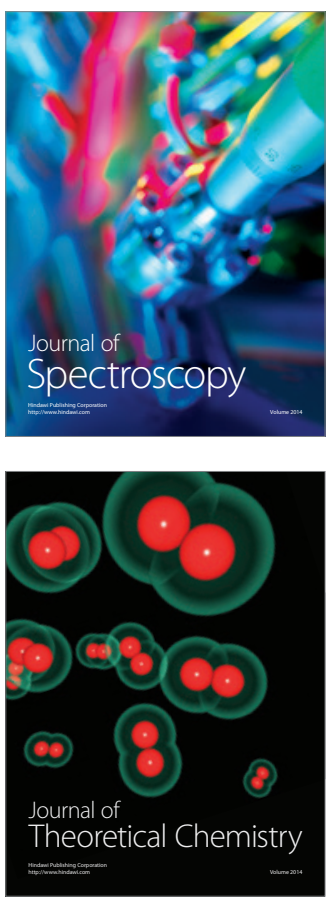
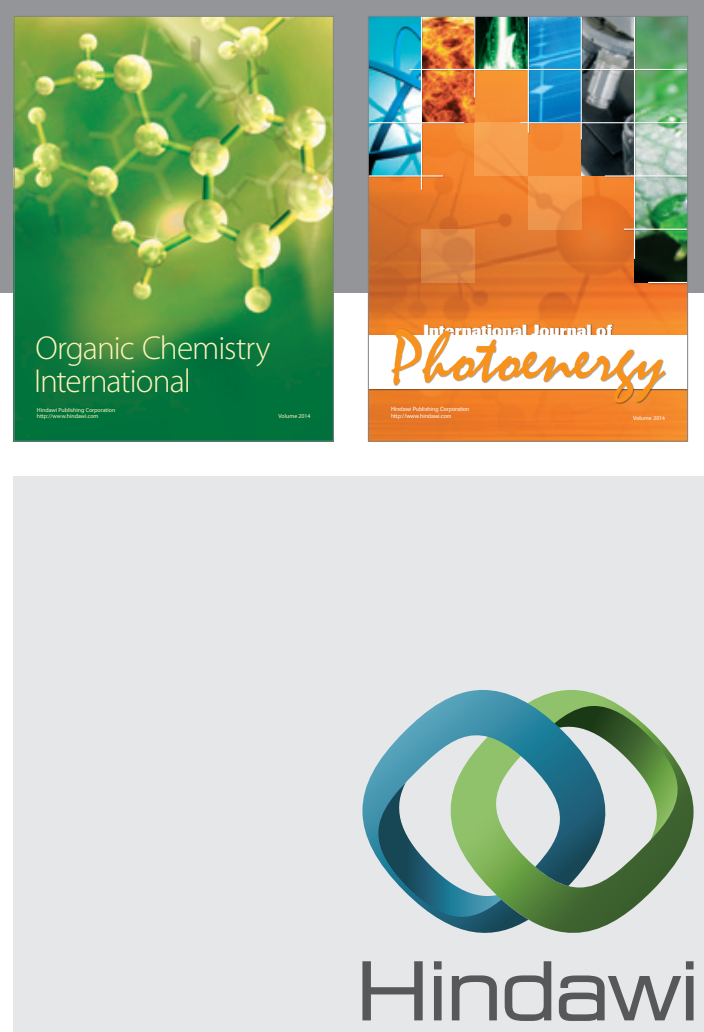

Submit your manuscripts at

http://www.hindawi.com

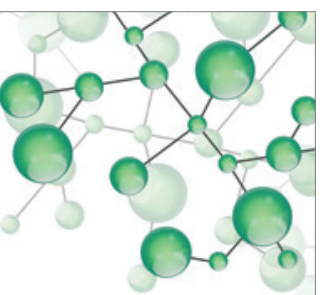

International Journal of

Inorganic Chemistry

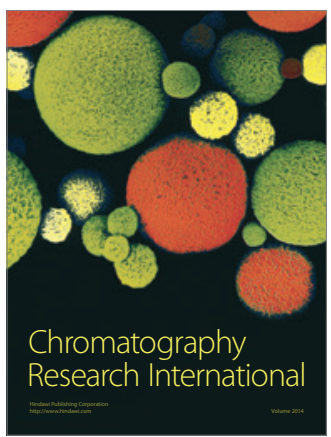

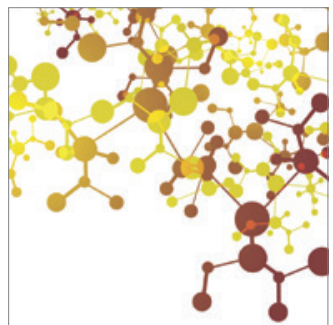

Applied Chemistry
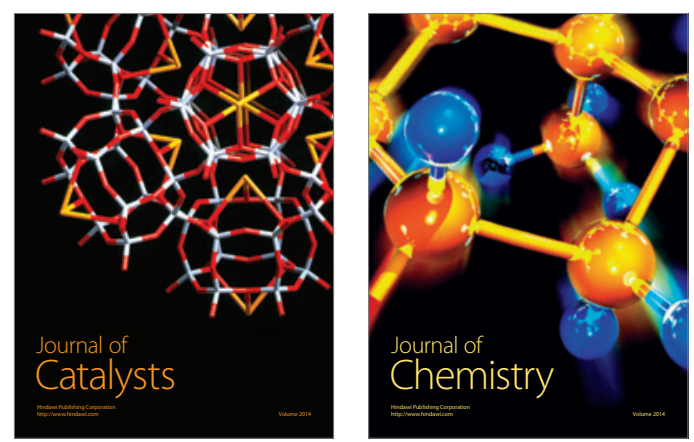
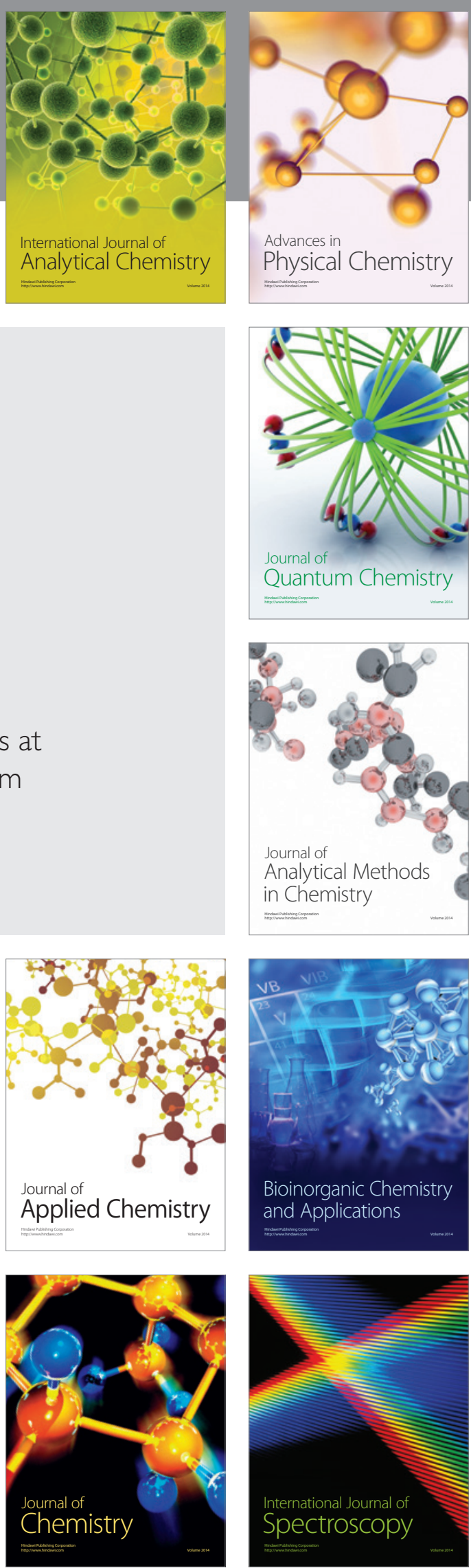